\title{
Six Steps from Visual Metaphors to Knowledge Transfer
}

\section{Ekaterina Isaeva}

PhD, Associate Professor, Perm State University; ekaterinaisae@gmail.com

\section{Svetlana Mishlanova}

PhD, Professor, Head of Department, Perm State University; mishlanovas@mail.ru

\author{
Doi:10.5901/mjss.2015.v6n6s5p228
}

\begin{abstract}
The paper presents evidence from research into the problem of knowledge transfer modalities and cognitive powers of the visual metaphor. We aim at developing a reliable method for visual metaphors identification. For this purpose we have employed up-to-date methods for linguistic metaphor identification and conceptual metaphors modelling, which have been modified in compliance with the data specifics. The Procedure has been applied for the extraction of knowledge, transferred via visual metaphors in the World War II propaganda posters by KUKRYNIKSI. The results obtained include visual metaphors and conceptual metaphor models simulated in the process of the six-step visual metaphor analysis, which provide deeper understanding and profound interpretation of the artists' intention; modification and validation of the methods for visual metaphors identification. In conclusion we discuss the perspectives of using the methods for other types of data.
\end{abstract}

Keywords: visual metaphor; metaphor identification; multimodal metaphor; knowledge transferred

\section{Introduction}

Anthropocentrism in modern science encouraged linguistics to go beyond the study of phonemes, morpheme, syntax and other discrete language units. According to Kibrik (2010) the attempts to separate language from communication, thinking, and behaviour are low constructive, non-natural, determined only by logic of scientific development but not the way things are. Due to this modern science turns its attention to various external stimuli of communication, namely to its multimodal constituent. The linguistic term 'multimodality' is adopted from psychology, neurophysiology, and informatics, which exploit the notion 'modality' defined as the type of external stimulus, perceived by sense organs, particularly visual and acoustic organs. Thus, such linguistic issues as prosody units, namely pauses, accents, tones, tempo, length, reduction and others are considered topical. Likewise visual communication in particular gestures, accompanying sound communication, are currently in the focus of modern linguistics (Kibrik, 2010, p. 134). For instance a multimedia audiovisual subcorpus of the Russian National Corpus with gesture tagging has been developed (http://www.ruscorpora.ru/en/ index.html).

Particularly new and rapidly developing branch of multimedia communication studies is metaphor research. The current stage of development of cognitive science puts forward a new approach to the interpretation of metaphor and its significance for knowledge transfer. In the present paper metaphor is defined as a cognitive mechanism of knowledge representation, based on mapping from a conceptual source domain to a conceptual target domain (Lakoff and Johnson, 1980), actualized in thought, in language, and in communication (Steen, 2009). Metaphor is in general use in different types of communication. Its wide spread can be explained by Conceptual metaphor theory, which claims, that we think and act in terms of metaphorical frames (Lakoff and Johnson, 1980).

The nature of metaphors, structuring our cognition and activity lies in understanding some events through the frames of other events, experienced earlier. According to G. Lakoff "frames are <...> structures of thought that we use every day. All words in all languages are defined in terms of frame-circuits in the brain. <... framing is about ideas, about how we see the world, which determines how we act" (Lakoff, 2011).

The mechanism works in the following way: the processing of new knowledge relies on the background knowledge (set of familiar frames) of an addressee and provides for mapping this knowledge into the conceptual sphere for interpreting the on-going event, thereby contributing to the categorization of new frames.

Conceptual metaphors can be objectified by language as well as other means of information representation. A lot of literature is available on the problems of metaphor in language identification and analysis (Pragglejaz Group, 2007; 
Steen, 2009, 2010; Krennmayr, 2011; Badryzlova et al., 2013), metaphor in thought modelling (Lakoff and Johnson, 1980, Lakoff 2006; Steen 2007; Alekseeva et al. 2013; Bogatikova \& Isaeva, 2014) but modalities of metaphor have not been so extensively researched. The most prominent contribution to the development of multimodal approach to metaphor is made by A. Cienki and K. Muller who focused their scientific interests on gesture studies, in particular their fundamental principles, metaphoricity of gestures, and correlation between metaphor in language and in gestures.

Visual representation is one of metaphor modalities. It is considered an effective cognitive tool used in various multimodal communicative events (Šorm \& Steen, 2013, p. 1). A breakthrough research has been conducted by G. Steen and $\mathrm{E}$. Šorm, who have developed a model of visual metaphor perception on the bases of H. Leder's aesthetic processing model (Leder et al., 2004) and Metaphor identification procedure - MIPVU (Pragglejaz Group, 2007).

In short the procedure of visual metaphor perception includes three main stages:

1. Incongruity perception implies mismatch between the basic (more concrete, body related) and contextual (specific for the event) meanings of the unit under analysis. This stage includes perception of patterns, colour, contrast, etc., comparison with the background knowledge, recognition of objects and scenes.

2. Incongruity resolution is implemented by recognizing conceptual mappings between the source and the target domain elements.

3. Contextual processing means additional information acquisition. This step provides deeper insight into the author's intention.

The existence of these stages has been proved by experimental evidence that reasons triggering mechanism of incongruity appearing in visual metaphor (Šorm \& Steen, 2013, p. 11).

Extensive use of visual metaphor in communication and an increasing interest in the ways visual metaphor application in the real world raise a concern in precise and reliable methods for visual metaphor identification. For this reason The Metaphor Lab Amsterdam has developed the corpus of visual metaphors "VisMet Corpus", an online resource of annotated images.

\section{Methods and Data Analysis}

Our attempt, demonstrated in this paper, is to modify the Five-step method of metaphor identification by G. Steen (2007), that allows identifying metaphor related words and context related conceptual metaphors in text into a procedure convenient for visual metaphor interpretation.

Whereas interpretation of both linguistic and visual metaphors are triggered by the same incongruity perception mechanism, we employ the method for linguistic metaphor identification (MIPVU) with minimal changes:

I. Examine the picture to establish a general understanding of the meaning.

II. Determine visual elements, i.e. objects, their features, and actions.

a) For each visual object in the text, establish its contextual meaning.

b) For each visual element, determine if it has a more basic contemporary meaning in other pictures than the one in the given picture. Basic meanings tend to be more concrete (what they evoke is easier to imagine, see, hear, feel, smell, and taste), related to bodily action, more precise (as opposed to vague).

This step implies the usage of word dictionaries, for example The American Heritage Dictionary of the English Language https://www.ahdictionary.com/, The Free Online English Dictionary from Macmillan Publishers http://www.macmillandictionary.com/, or The Longman Dictionary of Contemporary English Online http://www. Idoceonline.com/.

c) If the visual element has a more basic contemporary meaning in other pictures than in the given picture, decide whether the contextual meaning contrasts with the basic meaning but can be understood in comparison with it.

III. If yes, mark the visual element as metaphorical.

The Five-step method has been used in its original state but a supplementary sixth step, especially relevant for visual metaphor interpretation has been added.

\section{Results and Discussion}

The methods, presented above have been used for interpreting The Kukryniksy posters of the World War II period ${ }^{1}$. In

${ }^{1}$ The article uses the data from a course project (2014) 'Conceptual Analysis of Multimodal Representation of Political Propaganda in Posters of the KUKRYNIKSY during World War II' by S. Balandin, Perm State University (supervisors S. Mishlanova, E. Isaeva). 
this paper we will examine the poster "All the Calendars Lie" (1942) (see Figure 1).

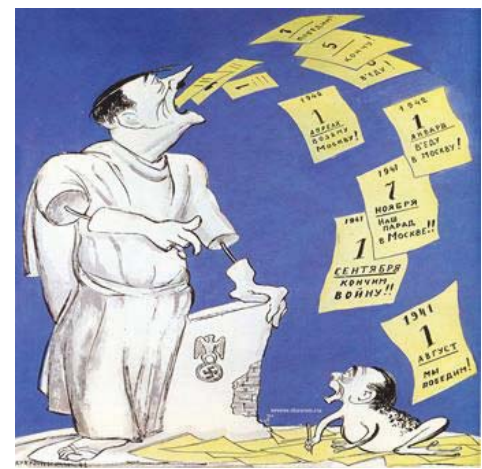

(C)2002-2015 Андрей Балашов. Davno.ru

Figure 1.

http://www.davno.ru/assets/images/posters/kukryniksy/big/kukryniksy-32.jpg)

The visual elements, distinguished in the poster, are connected with Hitler personality: the Roman statue with Hitler's head, partly ruined (ancient), hands detached from the body but fixed to it with reinforcing wires, as if prepared for an exhibition, some fingers are missing, a lectern, made of brick, partly covered with peeled off plaster, calendar pages, flying out of the Hitler's mouth, the dates and the notes "We will conquer!", "End the war!!", "Our march-past!!" etc.

Step 1. 'Metaphor focus identification', involves the identification of a metaphorical visual element used non-literally in the picture - 'The focus $\langle\ldots\rangle$ activates a concept which cannot be literally applied to the referents in the world evoked by the text.'(Steen, 2009: 197) Identification of metaphor focus is carried out in the current research with the exploitation of modified MIPVU.

\subsection{Fly Out}

Contextual meaning: if ideas or opinions are flying, people are talking about them a lot [http://www.macmillandictionary. com/dictionary/british/fly_1]

Basic meaning: to use wings to move through the air [http://www.macmillandictionary.com/dictionary/british/fly_1]

\subsection{Page}

Contextual meaning: declaration, promise (not presented in the dictionary)

Basic meaning: one side of a sheet of paper in a book, newspaper, or magazine [http://www.macmillandictionary. com/dictionary/british/page_1]

\subsection{Calendar}

Contextual meaning: (related to the title of the poser "All the calendars lie" (1824) and a similar expression from the comedy 'Woe from Wit' by A.S. Griboyedov) cited ironically about all kinds of newspaper forecasts, weather reports, predictions of astrologers interpretations of dream-books, etc. [translated from the Encyclopedic Dictionary of winged words and expressions http://www.bibliotekar.ru/encSlov/3/192.htm].

Basic meaning: a set of pages showing the days, weeks, and months of a particular year [http://www.macmillan dictionary.com/dictionary/british/calendar] (In "Woe from Wit" it refers to the address-calendar - "under this title calendar yearbooks with a list of institutions and individuals (with an indication of rank) were published" (Griboyedov, 1969, p. 383).

\subsection{Statue}

Contextual meaning: [Hitler's specific personality traits (see the interpretation in the 'Sixth step' section)]

Basic meaning: a human or animal image that is made of stone, wood, metal etc. and is usually large [http://www.macmillandictionary.com/dictionary/british/statue] 


\subsection{Ancient}

Contextual meaning: appeal to some old-fashioned Hitler's traits, expressed by the statute

Basic meaning: very old [http://www.macmillandictionary.com/dictionary/british/ancient]

\subsection{Lectern}

Contextual meaning: [Hitler's fascination with the art of oratory]

Basic meaning: a tall piece of furniture with a sloping surface where you put an open book or document when you are giving a speech [http://www.macmillandictionary.com/dictionary/british/lectern]

Step 2. 'Metaphorical idea identification', bridges the gap between discourse and conceptualization. At this level of study, the metaphorical focuses distinguished in step 1 are regarded as visual elements of concepts which are related to other concepts in a non-literal way. These relationships can be graphically represented in the form of propositions. A proposition is a minimal idea unit consisting of one predicate and one or several arguments. The result of a propositional analysis is a hierarchically organized list of propositions that presents the structural relations between the concepts contained by the idea units (Steen, 2009).

The example under analysis is built of six propositions in which P1-P6 stand for enumerated propositions, $\mathrm{s}$ expresses source domain of metaphorical mapping and MOD indicates attributive relation between the argument and its modifier. In our example the propositional analysis of the visual elements, related to the statue of Hitler, is conducted.

P1 (FLY OUTS PAGESS HEADt)

P2 (MOD HEADt, HITLERt)

P3 (MOD STATUES P2t)

P4 (MOD STATUES ANCIENTS)

P5 (MOD PAGES CALENDARS)

P6 (MOD CALENDARS NOTE ["We will conquer!", "End the war!!", "Our march-past!!"]t)

Step 3. 'Metaphorical comparison identification' explores the idea of metaphorical expressions in the form of propositions containing concepts in the literal and figurative sense. Since metaphors represent a set of relationships between the conceptual domains, in which figurative meaning is essential (Steen, 2009), the current stage of the analysis has to be concentrated at the reconstruction of the conceptual basis of non-literal comparison with the definition of open semantic slots.

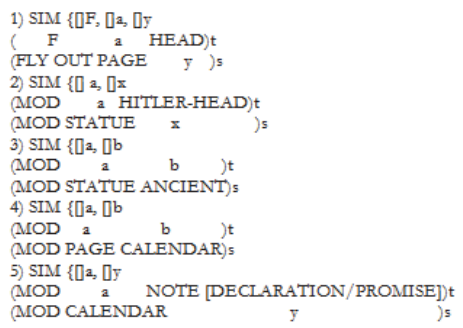

Step 4. 'Nonliteral analogy identification', enables filling in the slots left open in Step 3. This activity implies the analyst's inferring literal conceptual meanings variables $a, b, G, x, y$, and $F$ are standing for, as well as entities and relations evoked in non-literal comparison.

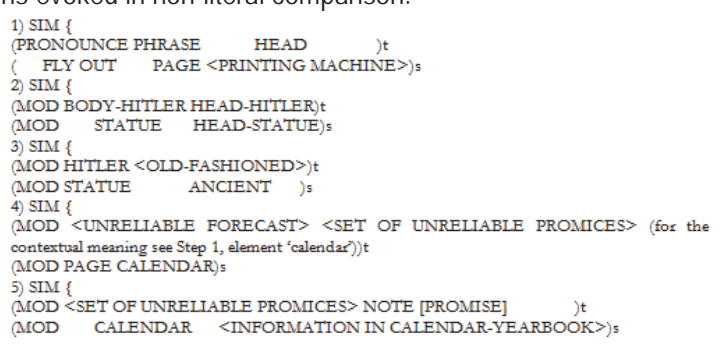

The fourth step gives grounds for the reliable identification of metaphorical mapping, to be executed at step five.

Step 5. Metaphorical mapping identification'. Verification of analogies received in step four results in a list of all the identified relations, represented as logical consequences and reflecting interdomain projection of concepts. 


\section{Table 1.}

\begin{tabular}{|l|l|}
\hline Source Domain & Target Domain \\
\hline FLY OUT & PRONOUNCE \\
PAGE & PHRASE \\
PRINTING MACHINE & HEAD \\
STATUE & BODY-HITLER \\
HEAD-STATUE & HEAD-HITLER \\
STATUE & HITLER \\
ANCIENT & OLD-FASHIONED \\
PAGE & UNRELIABLE FORECAST/ PROMICE \\
CALENDAR & SET OF UNRELIABLE FORECAST/ PROMICES \\
INFORMATION IN CALENDAR-YEARBOOK & NOTE \\
\hline
\end{tabular}

Step 6. 'Possible inferences'

Roman statue with the head of Hitler and the lectern symbolize Hitler's commitment to public speaking, popular in Rome, as well as the ambitions of Hitler as a conqueror and oppressor of nations and states that are typical of the old era and the Roman Empire. The statue may include the implication of the great, immortalized in history, so can express Hitler's claims for his historical immortality.

Taking into account the fact calendar pages as if automatically at high speed fly out of the statue's mouth, one can notice another implication: the statue is the symbol of lifelessness, loss of touch with reality, rigidity (Hitler loses touch with reality, continuing to make promises, as some automated statue or a printing machine).

The symbolic meanings of the statue and the lectern in the poster are not straightforward and encourage generation of various modifications and combinations of meanings, which can go beyond the objects' frames.

The ancient statue has lost its wholeness, which is also symbolic, abstract, and meaningful. It can contribute to all the frames evoked by the statue. It appeals to Hitler's old-fashioned military rhetoric, the failure of his ambitions for global military domination. It may reflect the irony about his ambitions on the historical immortality, about the fact that he has lost touch with reality. Beyond the quality of an abstract object decrepitude in the poster expresses some abstract quality. It may exhibit the Artists' ironical attitude, resided in the ultimate abstraction of the contextual meaning, while the basic meaning is pretty precise and complements the concrete meaning of 'statue'.

Calendars refer to Hitler's unreliable forecast, his unfulfilled promises distributed by Nazi press and propaganda. Here we deal with a visualized phraseological unit. When the quote from 'Woe from Wit' had become an eloquent expression, the word 'calendars' changed its semantics from rather explicit resource of information related to the dates of the year to all kinds of unreliable forecasts and predictions. This transformation is due to the fact that the basic meanings of both the calendars and forecasts are connected with the category of time. This visual metaphor is calqued from a linguistic one, preserving its Source and Target domains. The poster depicts both meanings: Hitler's forecasts and promises are written on usual calendar pages. That is why we can't interpret the meaning of the calendar univocally, since its Source and Target domains overlap. Nevertheless the obvious difference between the basic (concrete) meaning and related to forecasts and promises contextual (abstract) meaning. But we can not assert that the contextual meaning is derived from the basic one. It is more likely, that their relations are copied from the development of 'calendar' semantics from the calendar as a reliable yearbook to forecasts and promises.

Beside the visual elements, metaphorically related to the statue of Hitler, we can see a creature with Goebbels's head and a toad's body, looking at the statue of Hitler with his mouth open and eyes wide. Obviously, it adds something to the notes on the calendar pages flying out of the statue's mouth. Below we provide our interpretation of this visual element in brief.

Contextual meaning:

a) The purpose of the Goebbels-Toad character is to demonstrate how miserable and disgusting the enemy is. The toad image includes associated implications of deformity. Bulging eyes and an open mouth, typical of frogs, remind the reaction of the person with the utmost attention and admiration listening to someone else, "looking in the mouth". It is assumed that Hitler's followers praise and trust his every promise, no matter how unreliable it is.

b) the Reich Minister of Propaganda in the likeness of a toad, adding something to Hitler's notes symbolizes the way Hitler's claims are amplified and replicated by the propaganda machine.

Basic meaning:

a) toad - «a small animal that is similar to a frog but has brown skin and lives mainly on land» 
[http://www.macmillandictionary.com/dictionary/british/toad].

b) Paul Joseph Goebbels was a German politician and Reich Minister of Propaganda in Nazi Germany from 1933 to 1945.

Contextual meaning vs. basic meaning:

a) The contextual meaning can be derived from the basic meaning (similar reaction of an impressed listener and a toad's specific features). The contextual meaning of the toad as a signification of the negative attitude to Goebbels, as a symbol of Nazi propaganda, is ultimately abstract in comparison with the basic meaning.

b) The basic meaning - Goebbels's personality is concrete in comparison with the contextual meaning, including the Nazi propaganda machine, responsible for the stylistic editing and competing of Hitler's promises. The contextual meaning can be easily derived from the basic one, as far as Goebbels was the minister of propaganda.

\section{Conclusion}

The analysis presented in this paper exemplifies the usability of the modified Metaphor identification procedure (MIPVU) and Five-step method for visual metaphor identification. Moreover we contributed to the evidence of the framing powers and cognitive mechanisms of the visual metaphor that can be successfully employed for knowledge transfer. We also believe that the methods, updated and refined, can be extrapolated to other modalities of information representation, namely audio and video data. The choice of the data for the analysis has also proved its topicality due to its appeal to political morality and patriotic education as the timely demands of modern society.

\section{Acknowledgements}

The authors are grateful to the Russian Foundation for Basic Research and the Russian Foundation for Humanities for research grants № 14-06-31143 (RFBR), 14-13-59007 a/p (RFH), 15-16-59006 a/p (RFH) during which the projects on the study of knowledge transfer and conceptual modelling were completed.

\section{References}

Alekseeva, L.M., Isaeva, E.V., Mislanova, S.L. (2013). Metaphor in Computer Virology Discourse. World Applied Sciences Journal, 27 (4), 533-537.

Badryzlova, Y.G., Isaeva, E.V., Kerimov, R.D, Shehtman, N.G. (2013). Pravila primenenia procedury lingvisticheskoi identifikacii metafory (MIPVU) v russkoiazychnom korpuse: lingvokognitivnyi opyt (utochnenia i dopolnenia [The Rules for Metaphor Identification Procefure (MIPVU) in a Russian Corpus: Lingua-cognitive Experiment (refinements)]. Gumanitarnyi vector, seriia Filologiia, Vostokovedenie № 4 (36). Chita: Izdatel'stvo Zabaikal'skii gosudarstvennyi universitet, 19-29.

Bogatikova, E.P., Isaeva, E.V. (2014). Kommunikaciia special'nogo znaniia v kontekste krossdiskursivnyh issledovanii [Special Knowledge Communication in the Context of Crossdiscursive Terminology Research]. European Social Science Journal ,№ 6 (2), 101-107.

Griboiedov, A.S. (1969). Gor'e ot uma. Moskva: Nauka.

Kibrik, A. (2010). Mul'timodal'naia lingvistika. Kognitivnyie issledovania (4). Moskva: IP RAN, 134-152.

Krennmayr, T. (2011). Metaphor in Newspaper. The Netherlands.

Lakoff, G, Johnson, M. (1980). Metaphors we live by. Chicago: Chicago University Press.

Lakoff, G. How to Frame Yourself: A Framing Memo for Occupy Wall Street [Online] Available: http://www.huffingtonpost.com/georgelakoff/occupy-wall-street_b_1019448.html (October 10, 2015).

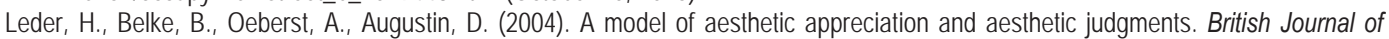
Psychology, № 95, 489-508.

Pragglejazz Group (2007). MIP: A method for identifying metaphorically used words in discourse. Metaphor \& Symbol 22, 1-39.

Šorm, E., Steen, G. (2013). Processing visual metaphor. Metaphor and the Social World 3:1. Amsterdam: John Benjamin Publishing Company, 1-34.

Steen, G. (2009). From linguistic form to conceptual structure in five steps: analyzing metaphor in poetry. In Cognitive poetics: Goals, gains and gaps, ed. G. Brône and J. Vandaele (Berlin; New York: Mouton de Gruyter,), 197-226. 